\title{
РЕАЛІЗАЦІЯ ДУАЛЬНИХ ФОРМ НАВЧАННЯ В ЄВРОПЕЙСЬКИХ УНІВЕРСИТЕТАХ
}

\section{М. Г. Дернова, В. В. Перевознюк}

Кременчуцький національний університет імені Михайла Остроградського

вул. Першотравнева, 20, м. Кременчук, 39600, Україна. E-mail: maya.dernova@ukr.net

Вітчизняна вища освіта сьогодні стоїть перед рядом викликів через недостатній рівень готовності багатьох випускників до самостійної професійної діяльності на перших робочих місцях, що відповідають здобутій освіті; незадоволеність ринку праці якістю освіти, що призводить до потреби у додатковому навчанні на робочому місці, тощо. За цих умов вкрай необхідним є пошук шляхів нового партнерства між вищою освітою і світом праці, а також роботодавцями з урахуванням потреб усіх учасників освітнього процесу. У цьому контексті вивчення досвіду дуальних форм навчання у європейських університетах викликає значний інтерес, і може стати важливим джерелом всебічного осмислення й творчого використання його позитивних ідей. У статті аналізуються дуальні форми навчання та їх зміст в університетах Німеччини, Австрії та Великої Британії. Визначено низку ознак, які роблять дуальну форму навчання ефективним інструментом не тільки для реформування української вищої освіти, але і для підприємств у справі підвищення кваліфікації й інтелектуалізації фахівців.

Ключові слова: вища професійна освіта; дуальне навчання; підготовка вчителів у Великій Британії; партнерство у вищій освіті.

\section{РЕАЛИЗАЦИЯ ДУАЛЬНЫХ ФОРМ ОБУЧЕНИЯ В ЕВРОПЕЙСКИХ УНИВЕРСИТЕТАХ}

\section{М. Г. Дернова, В. В. Перевознюк}

Кременчугский национальный университет имени Михаила Остроградского

ул. Первомайская, 20, г. Кременчуг, 39600, Украина. E-mail: maya.dernova@ukr.net

Отечественное высшее образование сегодня стоит перед рядом вызовов из-за недостаточного уровня готовности многих выпускников к самостоятельной профессиональной деятельности на первых рабочих местах, соответствующих полученному образованию; неудовлетворенности рынка труда качеством образования. В этих условиях крайне необходимым является поиск путей нового партнерства между высшим образованием и работодателями с учетом потребностей всех участников образовательного процесса. В этом контексте изучение опыта дуальных форм обучения в европейских университетах вызывает значительный интерес и может стать важным источником всестороннего осмысления и творческого использования его положительных идей. В статье анализируются дуальные формы обучения и их содержание в университетах Германии, Австрии и Великой Британии. Определен ряд признаков, которые делают дуальную форму обучения эффективным инструментом не только для реформирования украинского высшего образования, но и для предприятий в повышении квалификации и интеллектуализации специалистов.

Ключевые слова: высшее профессиональное образование; дуальное обучение; подготовка учителей в Великой Британии; партнерство в высшей школе.

АКТУАЛЬНІСТЬ РОБОТИ. У Національній доктрині розвитку освіти в Україні наголошено, що освіта має стати стратегічним ресурсом поліпшення добробуту людей, забезпечення національних інтересів, зміцнення авторитету і конкурентоспроможності держави на міжнародній арені. Проте стан справ у галузі вищої освіти, темпи та глибина перетворень не повною мірою задовольняють потреби особистості, суспільства й держави. Наразі українська вища освіта стоїть перед рядом викликів, пов'язаних із сучасними світовими тенденціями розвитку суспільства та промисловості. Процеси глобалізації, інтеграції й інформатизації, утвердження пріоритетів сталого розвитку, інші виклики сучасній цивілізації потребують вдосконалення форм, що забезпечують доступ до вищої освіти і підготовки упродовж життя, оновлення іiі змісту, запровадження світових стандартів, впровадження нових технологій тощо.

Сучасне педагогічне бачення освітніх проблем значною мірою грунтується на досягненнях вітчизняної педагогічної теорії (Г. Балл, І. Бех, В. Биков, С. Гончаренко, М. Гриньова, О. Дубасенюк, І. Зязюн, В. Кремень, Л. Лук'янова, В. Моляко, Н. Ничкало, С. Сисоєва та ін.).
Аналіз сучасного стану вітчизняної вищої освіти свідчить, що іï практична складова перебуває у критичній ситуації через низку обставин, які обумовлені економічними, фінансовими та організаційними чинниками. Це, у свою чергу, призвело до недостатнього рівня готовності багатьох випускників до самостійної професійної діяльності на перших робочих місцях, що відповідають здобутій освіті; незадоволеності ринку праці якістю освіти, що призводить до потреби у додатковому навчанні на робочому місці, розширенню системи навчання на підприємствах; неефективного використання бюджетних коштів через те, що надмірно велика частка випускників закладів освіти не працюють за здобутими професіями тощо.

За цих умов вкрай необхідним $є$ пошук шляхів нового партнерства між освітою і світом праці, а також роботодавцями 3 урахуванням потреб усіх учасників освітнього процесу.

Одним із шляхів вирішення зазначених проблем в умовах інтеграції України до європейського та світового освітнього простору, процесів глобалізації, інтернаціоналізації, забезпечення мобільності фахівців є не тільки звернення до найкращих зразків вітчизняної педагогічної спадщини, а й урахування загальних тенденцій європейського розвитку вищої 
професійної освіти, результатів європейських досліджень, прогресивних ідей європейського досвіду. Однією з таких ідей вважається дуальна форма навчання у закладах вищої освіти, яка має певні традиції в університетах європейських країн.

Випускники дуальних програм навчання характеризуються високим рівнем працевлаштування, причому 85\% підписують фіксований контракт про працевлаштування до закінчення навчання. За результатами дослідження Федерального інституту професійної підготовки у ФРН (Bundesinstituts fur Berufsbildung) $76 \%$ опитаних підприємств цінують у своїх випускниках відмінні знання про хід виробничих й економічних процесів; кожна друга фірма (45,6 \%) приймає на роботу свого практиканта після закінчення дуального навчання; майже 64 \% компаній переконані, що дуальних студентів відрізняє від інших висока мотивація й самостійність у роботі; більшість роботодавців відмічають у дуальних студентів високий рівень професійних навичок (46,5 \%) і вміння працювати в команді $(45,9 \%)$; три чверті опитаних компаній (74 \%) визнають дуальну форму вищої освіти якіснішою й ефективнішою у порівнянні з класичною.

Так, досвід німецької системи дуальної освіти став поштовхом для схвалення в Україні Концепції підготовки фахівців за дуальною формою здобуття освіти, метою якої є вироблення засад державної політики щодо підвищення якості професійної підготовки фахівців на основі дуальної форми здобуття освіти [1].

Втім, аналізуючи сучасні педагогічні дослідження українських дослідників, які вивчали проблеми вітчизняної вищої освіти (І. Каньковький, Л. Марцева, О. Муковіз, С. Прийма, Л. Султанова та інші) та зарубіжний досвід професійної підготовки фахівців в умовах університету (О. Авшенюк, С. Бабушко, С. Заскалєта, Г. Давиденко, Н. Креденець, О. Нітенко та інші), ми дійшли висновку, що досвід європейських країн щодо дуальних форм навчання на університетському рівні досліджено недостатньо. Тому вивчення досвіду дуальних форм навчання у європейських університетах викликає значний інтерес, і може стати важливим джерелом всебічного осмислення й творчого використання його позитивних ідей.

Мета дослідження - проаналізувати дуальні форми навчання в університетах Німеччини, Австрії та Великої Британії, визначити їх особливості.

МАТЕРІАЛ І РЕЗУЛЬТАТИ ДОСЛІДЖЕНЬ. Аналіз різних підходів до визначення сутності поняття дуального навчання у європейському просторі вищої освіти дає нам можливість синтезувати їх у наступних тезах:

1. Дуальне навчання - це підхід до вищої професійної освіти, у якому приорітетним вважається розвиток компетенцій через інтеграцію формального, неформального й інформального навчання.

2. Дуальне навчання базується на практикоорієнтованому підході до навчання, за допомогою якого студент набуває компетенції у контексті професійної діяльності. Під час практичної складової навчального процесу студент виконує теоретичний або прикладний науковий проект, який актуальний для навчального і професійного середовища.

3. Дуальне навчання відбувається у контексті організованого партнерства між роботодавцем, вищим навчальним закладом і студентом. Усі три сторони беруть участь у формуванні навчального плану i його реалізації.

Контингент дульних програм вищої професійної освіти в європейських університетах переважно складається із студентів денної форми навчання, які мають призначення на роботу, заплановане навчальною програмою; студенів денної форми навчання, які працюють неповний робочий день (за сумісництвом); дорослих, що мають повну зайнятість на робочому місці, але прагнуть підвищити освітній кваліфікаційний рівень в умовах вищого навчального закладу. Спільною рисою цих груп є те, що дорослі виконують роботу, або виконують роль працівника, водночас із навчанням в університеті [2].

У Загальноєвропейській платформі дуального навчання для закладів вищої професійної освіти [3] визначаються наступні його характеристики:

1. Дуальне навчання у вищій школі може бути визначено як поєднання формальної освіти і неформального або інформального емпіричного навчання, отриманого на місці професійної діяльності і через професійну діяльність.

2. Дуальне навчання може бути інтегровано в освітні програми, які оцінюються на рівні кваліфікацій відповідно до 6, 7 і 8 рівнів Свропейської рамки кваліфікацій.

3. Дуальне навчання робить вищу освіту життездатною, дає їй можливість чутливо реагувати на соціальні вимоги динамічних ринків праці, навчання впродовж життя i нових галузей трансдисциплінарних знань за допомогою:

- надання освітніх та науково-дослідних можливостей для студентів, тим самим покращуючи і полегшуючи безперервний професійний розвиток;

- підвищення цінності навчання, що забезпечує переваги для компаній, державних i приватних установ та організацій, або відповідає їх стратегічним цілям;

- зміцнення інноваційної діяльності вищих навчальних закладів та політики щодо навчання впродовж життя.

Навчальні програми у дуальних формах вищої освіти, як правило, мають наступні характеристики:

1. Студент має зобов'язання як робітник, або має договірні відносини з підприємством; узгоджує план навчання 3 представниками освітньої установи та підприємства; планує особисту траєкторію навчання.

2. Програма навчання відповідає потребам роботодавця і студента, а не заздалегідь складена освітньою установою в рамках дисциплінарного чи професійного контексту.

3. Відправна точка і освітній рівень програми встановлюється після того, як студент проходить процес визнання наявних компетенцій та ідентифікації навчання, у якому він бажає брати участь, а не на основі існуючої освітньої кваліфікації студента. 
4. Навчальні проекти, як правило, проводяться на робочому місці. Вони орієнтовані на проблеми робочого місця і майбутні потреби студента й підприємства. Частиною загального навчального плану можуть бути модулі інших провайдерів освітніх послуг та навчальних курсів.

5. Освітня установа оцінює результати навчання за договірними програмами відповідно до системи стандартів і рівнів кваліфікації. Така структура $є$ обов'язково транс-дисциплінарною [4].

Аналіз європейських досліджень із зазначеної проблеми (Д. Бауд (Baud D.), Дж. Бреннан (Brennan J.), Дж. Гарнетт (Garnett J.), Л. Граф (Graf L.), I. Каннінгем (Cunningham I.), К. Костлі (Costley C.), Б. Літтл (Little B.), I. Ніксон (Nixon I.), Дж. Релін (Raelin J.), Н. Соломон (Solomon N.), Б. Уокмен (Workman B.) та інші) свідчить про різноманітність дуальних форм навчання в університетах країн $\mathrm{C}_{\text {в- }}$ росоюзу. Зокрема Європейська комісія виокремлює три сучасних форми дуального навчання: навчання + учнівство, навчання + періодичне навчання в компанії й навчання + професійна діяльність (інтегроване навчання) [5]. Зазвичай освітня модель 3 інтегрованим навчанням передбачає варіації від двотижневих практик в рамках навчальної програми до підготовки фахівців за програмою дуального навчання, де студенти мають свій власний контакт 3 компані$€ ю$, а 4/5 частини навчання проходить у компанії [6].

У німецьких університетах дослідники [7] виокремлюють наступні форми дуального навчання:

1. Вища освіта інтегрована з професійною освітою (Ausbildungsintegrierende duale Studiengdnge) містить в собі класичну вищу освіту 3 практичною професійною підготовкою (перелік освітніх спеціальностей стандартизований). Умовою прийому на навчання $\epsilon$, як правило, атестат про середню або середню фахову освіту, а також угода 3 підприємством.

2. Вища освіта інтегрована 3 професійною діяльністю (Berufsintegrierende duale Studiengdnge): ця модель розрахована, у першу чергу, на тих, хто має завершену професійну освіту або багаторічний досвід роботи за будь-якою спеціальністю. Навчання припускає продовження професійної діяльності, якщо вона змістовно пов'язана 3 напрямком навчання. Ця форма навчання доступна без атестата про середню або середню фахову освіту, але обов'язковою є тристороння угода між університетом, студентом і підприємством.

3. Вища освіта інтегрована 3 виробничою практикою (Praxisintegrierende duale Studiengdnge): ця дуальної форма навчання передбачає проходження тривалої практики на підприємстві. Умовою прийому є атестат про середню або середню фахову освіту та угода з підприємством [8].

4. Вища освіта поєднана 3 професійною діяльністю (Berufsbegleitende duale Studiengdnge). Ці програми допомагають студентам, які мають або не мають сертифікату для вступу до університету або університету прикладних наук. Вони нагадують програми дистанційного навчання, оскільки учні, як правило, працюють повний робочий день і навчаються самостійно у вільний час або можуть відвіду- вати навчальні семінари. Однак, на відміну від програм дистанційного навчання, фірма повинна допомагати студентам успішно закінчити програму, наприклад, звільняючи їх від роботи (наприклад, під час занять у вищому навчальному закладі) або надаючи їм можливість отримати певний досвід роботи. На відміну від трьох вищезгаданих, ця форма навчання надає студенту більшої самостійності щодо інтегрування практичної й академічної складової навчання [9].

Стандартна модель вищої дуальної освіти в Німеччині передбачає, що практичні знання й навички (75-80 \% загального обсягу навчального часу) здобуваються на підприємстві. Навчальний заклад дає необхідні теоретичні й основні практичні знання (20-25 \% часу). Аналіз німецької системи вищої професійної освіти свідчить, що дуальні програми навчання реалізуються у вищих навчальних закладах різного типу: університетами прикладних наук (Universities of Applied Sciences, UAS) - (59\%), Державним університетом дуального навчання БаденВюртемберг (Baden-Wuerttemberg Cooperative State University, $D H B W)-(20 \%)$, професійними академіями (Berufsakademie) - (16\%) та класичними університетами - (3\%). Втім, німецькі дослідження визначають, що дуальні навчальні програми в університетах прикладних наук розвиваються найдинамічніше [10]. У ході дослідження нами також встановлено, що професійні академії наразі пропонують переважно навчальні програми інтегровані 3 виробничою практикою (Praxisintegrierende duale Studiengdnge) [9], тоді як університети прикладних наук і класичні університети зосереджені на програмах інтегрованих з професійною освітою (Ausbildungsintegrierende duale Studiengdnge) [8].

Розподіл годин практичного й академічного навчання у дуальних програмах німецьких університетів відбувається за інтегрованою, блочною і частковою моделями [11].

Аналіз дуального навчального плану зі спеціальності «Електротехніка» за освітнім рівнем Бакалавр у Баден-Вюртемберзькому державному університеті дуальної освіти свідчить, що дуальне навчання будується за блочною моделлю (навчальний блок триває 3 місяці). Зміст і терміни практичних етапів викладені у навчальних програмах, екзаменаційних вимогах і дескрипторах практичних модулів. Роботодавці стають учасниками освітнього процесу університету і беруть участь у розробці модулів через участь у робочих групах і комітетах.

На відміну від розгалуженої системи вищої професійної освіти Німеччини, в Австрії ядро університетської моделі дуального навчання складають університети прикладних наук. Вони пропонують дуальні програми як на рівні бакалавра, так і на рівні магістра. Програми в австрійських університетах прикладних наук мають широке визнання на ринку праці i, відповідно, їх випускники мають високий рівень конкурентоспроможності.

Дуальні навчальні програми в австрійських університетах прикладних наук містять блоки практичної роботи, що інтегровані 3 академічним навчанням. У цих програмах компанії розглядаються як 
освітні партнери, вони беруть активну участь у структуруванні навчального плану, розробці навчальних програм, а також відповідають за практичні етапи. Як правило, студенти навчаються за блочною схемою, де три місяці вони працюють на підприємстві, а три місяці навчаються в університеті. Практичний блок програми присвячується проекту або запланованим заходам, які узгоджуються 3 навчальною програмою і мають безпосередню практичну користь для компанії. Втім, аналіз навчальних програм австрійських університетів прикладних наук (UAS, Upper Austria; UAS, Vienna; FH Joanneum $U A S)$ свідчить, що деякі програми містять періоди практики на підприємстві впродовж усього періоду навчання (загальна кількість 20 тижнів) [12].

Щодо дуальних програм у британських університетах, слід зазначити, що ця форма здобуття вищої освіти практикується у більшості класичних університетів. Аналізуючи навчальні плани Честерського університету (University of Chester), Міддлсекського університету (Middlesex University), університету Дербі (University of Derbi) та Нотамбрійського університету (Northumbria University), можна виокремити наступні форми дуального навчання: індивідуальна (individual), дистанційна (distance learning), на підприємстві (in-house), інтегрована (integrated) і спільна (co-delivery). Індивідуальна модель вважається базовою в організації дуального навчання. За цією моделлю навчальний план узгоджується $з$ кожним студентом окремо, зважаючи на його попередній досвід, місце роботи, потреби його роботодавця тощо. Кожен студент просувається до бажаного результату за індивідуальним навчальним планом за допомогою тьютора. Якщо за індивідуальною формою студент відвідує заняття в університеті, то дистанційна форма дуального навчання надає можливість отримувати навчальні матеріали через електронну пошту, он-лайн консультації, тобо університет надає навчальні послуги за допомогою інформаційно-комунікаційних технологій. Це, у свою чергу, розширює географію проживання і роботи студентів. За формою in-house навчання відбувається на робочому місці на підприємстві, тому університет надає тьютора, який працює зі студентом у робочому середовищі, тобто за цією моделлю університет організує навчання студента за індивідуальним планом на підприємстві. Інтегрована форма дуального навчання передбачає розподілення зобов'язань щодо дизайну навчального плану студента, його забезпечення і оцінювання між університетом і підприємством. У спільній моделі навчання начальна програма ініціюється роботодавцем, узгоджується 3 університетом і студентом. За умовами цієї моделі студентів навчають акредитовані кваліфіковані робітники підприємства разом з викладачами університету. Студенту допомагають два тьютори: один - 3 боку університету, другий - 3 боку підприємства. Слід зауважити, що за цією програмою підприємство бере на себе основну відповідальність за організацію навчання і оцінювання [13].

Основними компонентами, які формують британський підхід до дуальної форми навчання в університетах слід вважати наступні:
1. Визнання попереднього досвіду й навчання, що забезпечує визначення обсягу навчальної програми і уможливлює скласти індивідуальний навчальний план студента.

2. Угода $з$ роботодавцем про навчання, де визначаються практичні і навчальні модулі відповідно до потреб студента. Угода грунтується на професійних потребах студента, його розвитку та інтересах роботодавця. Вона періодично переглядається та за необхідності коригується. Роль університету на даному етапі полягає у забезпеченні узгодженості програми та визначенню освітнього рівня, який здобуває студент.

3. Розробка методології дослідження, що розвиває навички критичної оцінки, планування та розробки проекту, що міститься у наступному етапі програми. Дослідницький компонент робить особливий акцент на аспектах дуального навчання, які мають вирішальне значення для розробки проекту, зокрема роль дослідника на робочому місці, значення контексту, в якому здійснюється проект, критична оцінка наукової літератури, а також вибір відповідного дослідницького підходу, що відображає умови робочого середовища, культуру та сферу професійної діяльності.

4. Виконання проекту або декількох проектів, що представляють інтерес і актуальність для робочого місця і відповідного освітнього рівня. Проекти дуального навчання спрямовані на полегшення опанування новими знаннями з академічних, юридичних та професійних джерел [14].

Між іншим, дуальні форми навчання ефективно реалізовані у британській системі підготовки вчителів, зокрема у шкільних та комбінованих програмах. Шкільні програми акцентовані на формування майбутнього вчителя під час професійної діяльності, виходячи 3 дослідницького характеру педагогічної діяльності. У комбінованих програмах - навчання організоване на партнерських засадах між університетом та школою, де студенти проходять педагогічну практику[15].

ВИСНОВКИ. Отже, аналіз дуальних форм здобуття вищої освіти в Німеччині, Австрії та Великій Британії дає можливість визначити їх загальні особливості, а саме:

1. Партнерство між основними зацікавленими сторонами, такими як: роботодавці, студенти та вищі навчальні заклади.

2. Формальне визнання попереднього навчання $\mathrm{i}$ досвіду через систему акредитації.

3. Наявність інноваційної складової навчання на основі методології «комбіноване навчання» (blended learning), в тому числі різні форми навчання та викладання, що характеризуються:

- критичною рефлексією і рефлексивними діями, котрі пов'язують нові теорії з досвідом;

- практико-орієнтованими проектами, які задовольняють потребам всіх зацікавлених сторін і обумовлюються у навчальному договорі;

- методологією і методикою дистанційного та електронного навчання;

- індивідуальною підтримкою студента як освітньою установою, так і роботодавцем. 
4. Основним методологічним підходом у дуальних формах навчання $\epsilon$ емпіричне навчання і його стратегіï.

5. Проектування програм залежить від попереднього й поточного досвіду роботи студента. Навчальні програми можуть складатися 3 кредитів різних джерел, зокрема:

- договірні модулі дуального навчання;

- існуючі модулі курсів в університеті;

- акредитовані короткострокові курси;

- акредитовані програми навчання, надані роботодавцем;

- акредитовані модулі або курси, пропоновані іншими освітніми установами;

- акредитація попереднього навчання.

Визначені відмінності роблять дуальну форму навчання ефективним інструментом як для реформування української вищої освіти, так і задоволення потреб студентів і підприємств у справі підвищення кваліфікації й інтелектуалізації фахівців. А відтак підвищення конкурентоспроможності економіки країни в цілому.

Перспективними напрямами дослідження $є$ вивчення шляхів упровадження європейського досвіду дуальної освіти у професійну підготовку фахівців в університетахУкраїни.

\section{ЛІТЕРАТУРА}

1. Концепція підготовки фахівців за дуальною формою здобуття освіти. Схвалено розпорядженням Кабінету Міністрів України від 19 вересня 2018 р. № 660-p https://zakon.rada.gov.ua/laws/show/6602018-\%D1\%80

2. Little B. et al (2006) "Employability and Work-based Learning. ESECT Learning and Employability Series", Series One, Guide No. 7. York, Higher Education Academy. [Online]. Available: http://www.heacademy.ac.uk/assets/York/documents/ou rwork/tla/employability/id114_employability_and_work -based_learning_591.pdf [Accessed: 25 October 2014].

3. Light B. (2008) "Growing work based learning in Europe", DProf thesis, Institute for Work-Based Learning, Middlesex University, London, UK. [Online]. Available: http://eprints.mdx.ac.uk/9117/ [Accessed: 25 April 2019].

4. Boud D., Solomon N. "Work as the curriculum: Pedagogical and identity implications" in UTS Research Centre Vocational Education \& Training. Proceedings of International Conference on Working Knowledge: Productive learning at work, University of Technology Sydney, New South Wales, Australia Working Paper 07, University of Worcester, 10-13 December 2000. [Online]. Available: http://www.worc.ac.uk/edu/documents/ worknow07(1).pdf [Accessed: 1 November 2014].

5. Work-based learning in Europe - Practices and Policy Pointers (2013), European Comission. [Online]. Available: http://ec.europa.eu/education /lifelonglearning-policy/doc/work-based-learning-ineurope_en.pdf [Accessed: 18 November 2013].

6. Hippach-Schneider, Ute "Work-based learning in Europe - Renewing Traditions" - background information, International BIBB Conference, Bonn 4 5 December, 2013. [Online]. Available: https://www.bibb.de/dokumente/pdf/stbpr_veranstaltung _2013_12_04_workbased_learning_in_europe_hintergr undpapier_en.pdf [Accessed: 18 November 2018].

7. Graf L. (2016) The rise of work-based academic education in Austria, Germany and Switzerland, Journal of Vocational Education \& Training, Journal of Vocational Education \& Training, 2016 VOL. 68, NO. 1, 1-16 http://dx.doi.org/10.1080/13636820. 2015.1107749

8. Minks, Karl-Heinz, Netz, Nicolai \& Vцlk, Daniel (2011) Berufsbegleitende und duale Studienangebote in Deutschland: Status quo und Perspektiven. HIS: Forum Hochschule 11. Hanover, Higher Education Information System (HIS). [Online]. Available: https://www.jobadu.de/pdfs/01754.pdf [Accessed: 25 April 2019]

9. Waldhausen, V., Werner, D. (2005) Innovative Ansдtze in der Berufsbildung -Нцhere Durchlдssigkeit und Flexibilitдt durch Zusatzqualifikationen und duale Studiengдnge. Forschungsberichte aus dem Institut der deutschen Wirtschaft Kųln Nr. 12. Cologne, Deutscher Instituts-Verlag. [Online]. Available: https://www.iwkoeln.de/fileadmin/user_upload/Studien/ IW-Analysen/PDF/Bd._12_Innovative_Ans\%C3\%A 4tze_in_der_Berufsausbildung.pdf [Accessed: 05 May 2019]

10. BIBB (2011) Integration of vocational and higher education in dual courses of study. Federal Institute for Vocational Education and Training (BIBB). [Online]. Available: https://www.bibb.de/en/29035.php [Accessed: 05 May 2019]

11. Mill, U. (2017). Dual education: experience of Germany. Marketing in Ukraine Journal, 17(1). [Online]. Available: http://uam.in.ua/rus/projects/ marketing-in-ua/arhive.php [Accessed: 25 May 2019]

12. Ferrández-Berrueco R., Kekale T., Devins D. (2016) "A framework for work-based learning: basic pillars and the interactions between them", Higher Education, Skills and Work-Based Learning, Vol. 6 Issue: 1, pp.35-54, https://doi.org/10.1108/HESWBL06-2014-0026

13. Major D. (2016) "Models of work-based learning, examples and reflections", Journal of WorkApplied Management, vol. 8, iss. 1, pp. 17-28, 2016. DOI: 10.1108/JWAM-03-2016-0003.

14. Workman B., Garnett J. (2009) The development and implementation of work based learning at Middlesex University. In: Work based learning: journeys to the core of higher education. Garnett, Jonathan, Costley, Carol and Workman, Barbara, eds. Middlesex U. P., London, pp. 2-14. [Online]. Available: https://eprints.mdx.ac.uk/ 5202/2/Workman_\%26_Garnett-introduction_to_ WBL.pdf [Accessed: 25 April 2019].

15. Dernova M., Perevozniuk V. (2018). University-Led Routes of Initial Teacher Training in Great Britain. Engineering and Educational Technologies, 6 (4), 66-75. doi: https://doi.org/10.30929/23079770.2018.06.04.07 


\section{IMPLEMENTATION OF DUAL LEARNING MODELS IN EUROPEAN UNIVERSITIES}

\section{Dernova, V. Perevoznyuk}

Kremenchuk Mykhailo Ostrohradskyi National University

vul. Pershotravneva, 20, Kremenchuk, 39600, Ukraine. E-mail: maya.dernova@ukr.net

Purpose. The article aims to review the practice of dual learning, based on the experience of higher education institutions in Germany, Austria and Great Britain. Methodology. The methods of system and comparative analysis, synthesis and generalization are used. Results. The background and development of dual learning programmes in European higher education is given; the importance and value of dual forms in the modern, rapidly changing society is shown. A number of features of dual learning in European universities have been identified. Among them are partnerships between three key stakeholders (employer, student and university); negotiated learning agreement; recognition of prior learning and experience; practical-oriented projects that meet the needs of all stakeholders; flexibility through distance, on-line and blended learning strategies; experiential learning as the main methodological approach; credits from different programmes, in particular contract modules; other modules at the university; accredited short-term courses; accredited training programs provided by the employer; accredited modules or courses offered by other universities. Originality. For the first time the analysis of dual learning forms and programmes content in universities of three European countries has been made. Main features of dual learning university programmes have been defined. Practical value. Results can be taken into account when planning and designing dual programmes in Ukrainian universities. Conclusions. The analysis of dual forms of higher education in Germany, Austria and the United Kingdom makes it possible to determine their general features. Among them are (1) partnership among key stakeholders (employers, university and student); (2) accreditation of prior learning and experience; (3) innovative learning component based on the blended learning methodology, including different forms of teaching and delivery; (4) experiential learning is a key methodological approach in dual forms; (5) programs designdepends on the previous and current student experience. Curriculum accepts credits from various courses and accreditation of previous learning. So dual learning can provide a holistic connection between university education and employment, make an invaluable contribution to the personal and professional development of students, better equip students for professional activities after graduation, and provide employers with high-quality specialists.

Key words: higher professional education; dual learning; work-based learning; teachers training in Great Britain; partnerships in higher education.

\section{REFERENCES}

1. Kontseptsiya pidhotovky fakhivtsiv za dual'noyu formoyu zdobuttya osvity. Skhvaleno rozporyadzhennyam Kabinetu Ministriv Ukrayiny vid 19 veresnya 2018 r. № 660-r https://zakon.rada.gov.ua/ laws/show/660-2018-\%D1\%80

2. Little, B. et al (2006), "Employability and Work-based Learning. ESECT Learning and Employability Series", Series One, Guide No. 7. York, Higher Education Academy, [Online], Available: http://www.heacademy.ac.uk/assets/York/documents/ou rwork/tla/employability/id114_employability_and_work -based_learning_591.pdf [Accessed: 25 October 2014].

3. Light, Barbara (2008), "Growing work based learning in Europe", DProf thesis, Institute for WorkBased Learning, Middlesex University, London, UK, [Online], Available: http://eprints.mdx.ac.uk/9117/ [Accessed: 25 April 2019].

4. Boud, D., Solomon, N. (2000), "Work as the curriculum: Pedagogical and identity implications" in UTS Research Centre Vocational Education \& Training. Proceedings of International Conference on Working Knowledge: Productive learning at work, University of Technology Sydney, New South Wales, Australia Working Paper 07, University of Worcester, 10-13 December 2000, [Online], Available: http://www.worc.ac.uk/edu/documents/ worknow07(1).pdf [Accessed: 1 November 2014].

5. Work-based learning in Europe - Practices and Policy Pointers (2013), European Comission, [Online], Available: http://ec.europa.eu/education/lifelonglearning-policy/doc/work-based-learning-ineurope_en.pdf [Accessed: 18 November 2013].
6. Hippach-Schneider, U. (2013), "Work-based learning in Europe - Renewing Traditions" background information, International BIBB Conference, Bonn 4-5 December, 2013, [Online], Available: https://www.bibb.de/dokumente/pdf/ stbpr_veranstaltung_2013_12_04_workbased_learning in_europe_hintergrundpapier_en.pdf [Accessed: 18 November 2018].

7. Graf, Lucas (2016), The rise of work-based academic education in Austria, Germany and Switzerland, Journal of Vocational Education \& Training, Journal of Vocational Education \& Training, 2016 Vol. 68, Iss. 1, pp. 1-16. http://dx.doi.org/10.1080/13636820. 2015.1107749

8. Minks, Karl-Heinz, Netz, Nicolai, Vцlk, Daniel (2011), Berufsbegleitende und duale Studienangebote in Deutschland: Status quo und Perspektiven. HIS: Forum Hochschule 11. Hanover, Higher Education Information System (HIS), [Online], Available: https://www.jobadu.de/pdfs/01754.pdf [Accessed: 25 April 2019]

9. Waldhausen, V., Werner, D. (2005), Innovative Ansдtze in der Berufsbildung -Hцhere Durchlдssigkeit und Flexibilitдt durch Zusatzqualifikationen und duale Studiengдnge. Forschungsberichte aus dem Institut der deutschen Wirtschaft Kuln Nr. 12. Cologne, Deutscher Instituts-Verlag, [Online], Available: https://www.iwkoeln.de/fileadmin/user_upload/Studien/ IW-Analysen/PDF/Bd._12_Innovative_Ans\%C3\%A 4tze_in_der_Berufsausbildung.pdf [Accessed: 05 May 2019]

10. BIBB (2011) Integration of vocational and higher education in dual courses of study. Federal Institute for Vocational Education and Training (BIBB), 
[Online]. Available: https://www.bibb.de/en/29035.php [Accessed: 05 May 2019]

11. Mill, U. (2017), Dual education: experience of Germany. Marketing in Ukraine Journal, 17(1), [Online], Available: http://uam.in.ua/rus/projects/ marketing-in-ua/arhive.php [Accessed: 25 May 2019]

12. Ferrández-Berrueco, Reina, Kekale, Tauno, Devins, David (2016), "A framework for work-based learning: basic pillars and the interactions between them", Higher Education, Skills and Work-Based Learning, Vol. 6 Issue: 1, pp. 35-54, https://doi.org/10.1108/HESWBL-06-2014-0026

13. Major, D. (2016) "Models of work-based learning, examples and reflections", Journal of WorkApplied Management, vol. 8, iss. 1, pp. 17-28, DOI: 10.1108/JWAM-03-2016-0003.
14. Workman, Barbara, Garnett, Jonathan (2009), The development and implementation of work based learning at Middlesex University. In: Work based learning: journeys to the core of higher education. Garnett, Jonathan, Costley, Carol and Workman, Barbara, eds. Middlesex U. P., London, pp. 2-14, [Online], Available: https://eprints.mdx.ac.uk/ 5202/2/Workman_\%26 _Garnett-introduction_to_ WBL.pdf [Accessed: 25 April 2019].

15. Dernova, M., Perevozniuk, V. (2018), University-Led Routes of Initial Teacher Training in Great Britain. Engineering and Educational Technologies, 6 (4), 66-75. doi: https://doi.org/10.30929/23079770.2018.06.04.07

Стаття надійшла 30.05.2019. 